\title{
REVIEW
}

\section{Thyroid hormone and central nervous system development}

\author{
S Chan and M D Kilby ${ }^{1}$ \\ Department of Obstetrics and Gynaecology, Birmingham Women's Hospital, Edgbaston, Birmingham B15 2TG, UK \\ 'Department of Fetal Medicine, Division of Reproductive and Child Health, University of Birmingham, Edgbaston, Birmingham B15 2TG, UK \\ (Requests for offprints should be addressed to M Kilby; Email: m.d.kilby@bham.ac.uk)
}

\section{Introduction}

It is well established that the thyroid status of neonates and children has a significant long-term impact on their behaviour, locomotor ability, speech, hearing and cognition (Legrand 1986). Delay in restoring normal thyroid status in the neonate can lead to irreversible damage. Prompt thyroid supplementation following the diagnosis of neonatal hypothyroidism can restore neurodevelopment to within the normal range (Fisher 1979). Even so, there are still subtle abnormalities of language, visuo-spatial impairments and lower mean IQs later in childhood compared with euthyroid controls. This implies that brain development may, in part, be thyroid hormone sensitive not only in the neonatal period but also prior to birth (New England Congenital Collaborative 1990, Heyerdahl 1991). Development of different areas of central nervous sytem has been associated with the timing and duration of thyroid hormone deficiency, suggesting that there are critical periods during which various parts of the brain are sensitive to thyroid hormone supply (Rovet et al. 1992).

\section{Central nervous system histology and the effects of thyroid status}

The clinical signs of neurodevelopmental delay can be explained by the accompanying histological and biochemical changes, mainly observed in animal models. Thyroid hormones regulate the processes of terminal brain differentiation such as dendritic and axonal growth, synaptogenesis, neuronal migration and myelination (Eayrs \& Taylor 1951, Eayrs \& Horne 1955, Eayrs 1955). In hypothyroid rats there is retarded development of the neuropil in the cerebral cortex and the cerebellar Purkinje cells. Neuronal bodies are smaller and more densely packed, there is diminished dendritic branching and elongation, as well as altered distribution of dendritic spines and delayed cell proliferation and migration (Nicholson \& Altman 1972). Deficiencies of myelination have been observed in the cerebral cortex, visual and auditory cortex, hippocampus and cerebellum, areas which relate to the observed neurodevelopmental delay (Balazs et al. 1969, 1971, Rosman et al. 1972). These findings, together with a marked decrease in the number and delayed maturation of microtubules within these cells, indicate potentially profound changes in the central nervous system compared with the euthyroid state (Legrand 1967, Faivre et al. 1984). All these effects in rats can be reversed by thyroid supplementation but only if supplementation is started before the end of the second week of extrauterine life. The greater the delay in thyroid replacement the less the chance of recovery (Eayrs 1971, Legrand 1986). Rat brain development is such that postnatal maturation corresponds to changes in the human brain which occur at the end of intrauterine life.

\section{Maternal and fetal thyroid status in the antenatal period}

Both maternal and fetal thyroid status in utero may be critical in brain development. In a reported case of Pit-1 deficiency, an inherited condition which results in severe hypothyroidism in both the mother and fetus secondary to failure of thyrotroph development, there was severe impairment in the neonate's neurological development together with delay in cardiopulmonary function and bone maturation (de Zegher et al. 1995). Observational studies performed in iodine-deficient parts of the world have shown that iodine supplementation before pregnancy and in the first and second trimesters reduces the incidence of cretinism but supplementation beginning later in pregnancy does not improve the neurodevelopmental status of the offspring (Pharoah et al. 1971, Cao et al. 1994). Even children of marginally iodine-deficient mothers show psychomotor and cognitive impairment (Pharoah et al. 1984). Such data indicates the sensitivity of the developing CNS to maternal thyroid metabolism in utero.

It has been clearly demonstrated that maternal thyroid hormones cross the placenta into the fetal circulation. In athyroid fetuses at term Vulsma et al. (1989) reported 

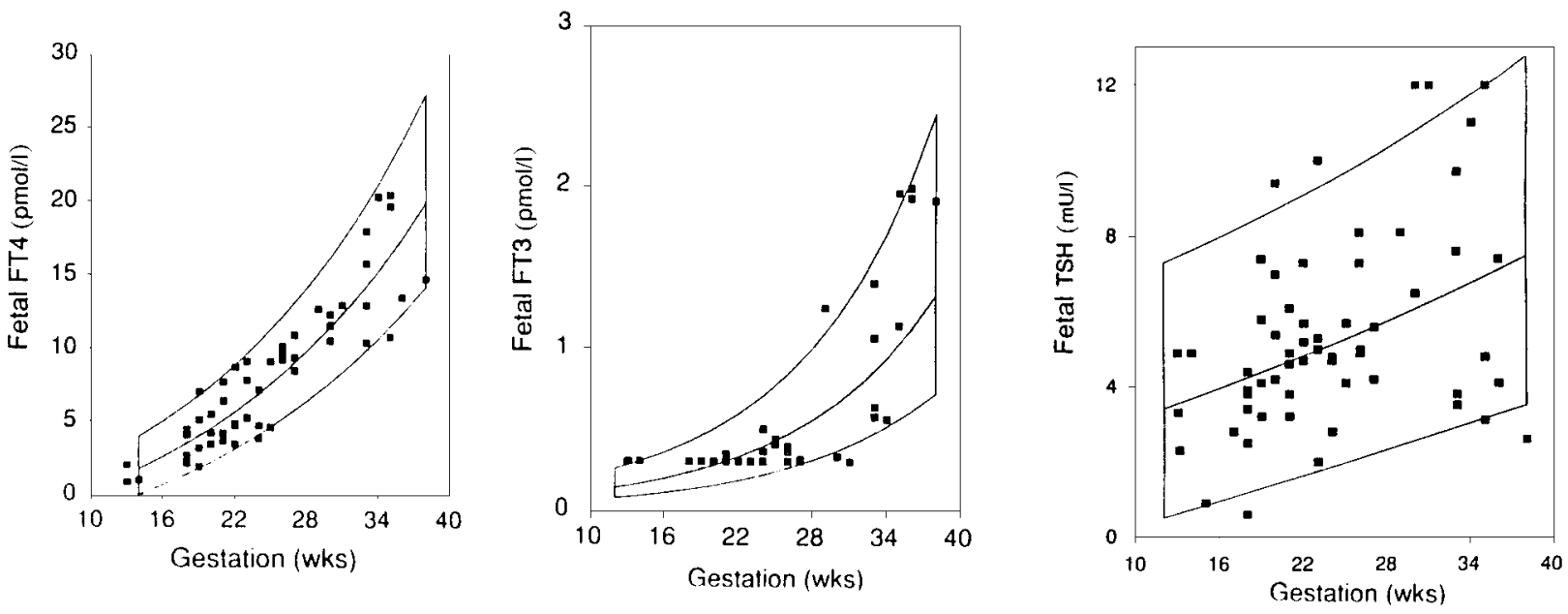

Figure 1 The ontogeny of fetal thyroid hormone metabolism. Concentrations of fetal TSH, T4 and T3 during gestation. Data from fetal blood samples obtained by cordocentesis (Thorpe-Beston et al. 1991b).

concentrations of circulating thyroid hormones around $25-50 \%$ those of normal infants. These concentrations appear adequate in preventing phenotypic expression of congenital hypothyroidism at birth and confer some protection of fetal brain development (Illig 1979). This may explain why in cases of human congenital hypothyroidism in which the mother is euthyroid neonatal thyroxine supplementation can result in neurodevelopment within the normal range (Fisher 1991).

In contrast, maternal hypothyroidism, not necessarily due to iodine deficiency, has been associated with poorer neuropsychological outcome in offspring. In the Netherlands, 220 mothers with a low serum free thyroxine (T4) concentration at 12 weeks gestation gave birth to babies who at 10 months of age had scores at or below the tenth percentile on the psychomotor developmental index of the Bayley scales of infant development (Pop et al. 1999). In the United States, mothers who had a low serum butanol-extractable iodine (a measure of circulating thyroid hormones employed in the 1960s) before 24 weeks gestation and who were not adequately treated, had infants with lower Bayley Scores. These children were later shown to have lower IQ scores at 4 and 7 years of age (Man et al. 1991). Recently, another study was performed in the United States on the offspring of 62 women with serum thyrotrophin (TSH) concentrations above the 98th percentile during pregnancy comparing them with 124 matched controls. None of the neonates had hypothyroidism at birth. The children were assessed between the ages of 7 and 9 years. Those with hypothyroid mothers performed less well on all 15 of the neuropsychological tests and had on average a 4-point lower IQ score on the Wechsler intelligence scale for children than the controls. Forty-eight of the 62 biochemically hypothyroid women were not treated during pregnancy as they were clinically euthyroid, and the children of this subgroup of women performed less well, with an average 7-point lower IQ score than controls. Nineteen per cent of these scored 85 or less. Interestingly, the serum total $\mathrm{T} 4$ and free $\mathrm{T} 4$ concentrations in the treated and the non-treated undiagnosed women were similar during pregnancy. This study demonstrates that subclinical hypothyroidism in women can result in neuropsychological deficits in their offspring, and thyroxine supplementation can improve the outcome even when supplementation is inadequate (Haddow et al. 1999). A further study in Canada suggested subclinical autoimmune hypothyroidism in the mother could be associated with a higher incidence of transient congenital hypothyroidism, probably through disruption of the fetal thyroid gland by the transplacental passage of maternal anti-thyroid antibodies. Unfortunately, the long-term neuropsychological outcomes in these children were not reported (Dussault \& Fisher 1999). Certainly in the rat, maternal hypothyroxinaemia has been shown to result in long-term biochemical and behavioural dysfunction in the progeny (Pickard et al. 1997).

\section{Circulating thyroid hormone concentrations in human pregnancy}

There is a rise in fetal circulating concentrations of total $\mathrm{T} 4$, free $\mathrm{T} 4$, free triiodothyronine (T3) and thyroxine binding globulin (TBG) with gestation (Fisher 1992, Burrow et al. 1994, Kilby et al. 1998) (Fig. 1). In the first and second trimesters there is a much higher concentration of free $\mathrm{T} 4$ in the maternal circulation compared with the fetal circulation. The difference decreases towards term as fetal thyroid function matures. However, even at term maternal serum free T3 concentrations are two- to 
threefold more than those in the fetus and approximately $30 \%$ of thyroid hormones measured in cord blood are still derived from the mother (Thorpe-Beeston et al. 1992, Delbert \& Fisher 1997b).

\section{Thyroid hormone concentrations in fetal brains}

In humans, both $\mathrm{T} 3$ and $\mathrm{T} 4$ can be detected in the first trimester brain before the fetal thyroid gland becomes active, possibly indicating that thyroid hormones transferred from the mother play an important role (Bernal \& Pekonen 1984, Sinha et al. 1997). T3 is not detectable in other fetal tissues apart from the brain at this stage, lending support to the theory that there is a specific role for thyroid hormones in very early brain development. T4 is detected in the brain at 11-14 weeks, the level increasing 2.5 times by $15-18$ weeks. Even after the fetus begins to produce its own thyroid hormones in the second trimester, maternal thyroid hormones make a significant contribution towards the supply to the fetal brain. This is indicated by positive correlations between maternal serum T4 concentrations, fetal cerebro-cortical T4 and maternal urinary iodine excretion at this stage (Sinha et al. 1997).

Concentrations of circulating thyroid hormones determine cellular supply to the brain and, in turn, effects at the cellular level are influenced by 5-monodeiodinase activity. T4 is converted to the active ligand T3 by type II 5 -monodeiodinases locally in brain tissue. The rise in circulating thyroid hormones is accompanied by evidence of increasing 5-monodeiodinase activity in the brain up to 19-22 weeks gestation but the activity declines thereafter (Sinha et al. 1997). The need to increase local T3 levels lends further support to the theory that thyroid hormones play an important role in brain development in the late first trimester and early second trimester.

Studies in the rat have shown that maternal T4 transported across the placenta can provide normal concentrations of T3 in hypothyroid fetal brains (Calvo et al. 1990). Also, brains of human fetuses carried by mildly iodine-deficient mothers with biochemical hypothyroidism have been reported to have T4 levels similar to those of normal fetuses in both the first and second trimesters of pregnancy. The T3 levels in the cerebral cortex of human fetuses normally peaks at 15-18 weeks gestation, coinciding with the onset of fetal thyroid hormone production. In mild iodine deficiency, however, T3 is maintained at a high level for longer, until 22 weeks gestation, but the absolute amount is still significantly less than in the iodine-sufficient group (Karmarkar et al. 1993). Activity of the type II 5-monodeiodinase enzyme is significantly higher in iodine deficiency and when the circulating T4 concentration is low (Leonard et al. 1984, Karmarkar et al. 1993, Sinha et al. 1994). All this evidence suggests that the preferential uptake of $\mathrm{T} 4$ by the thyroid hormone-deficient brain, together with the up-regulation of the enzyme occur as part of a compensatory homeostatic mechanism to improve thyroid hormone supply to the developing brain in iodine deficiency (Sinha et al. 1997). However, it is unlikely that in more severe maternal hypothyroidism this mechanism of compensation is capable of maintaining adequate thyroid hormone levels in fetal brains.

As mentioned earlier, mildly iodine-deficient and hypothyroid mothers do produce neurodevelopmentally compromised offspring and fetuses in such circumstances are known to have normal $\mathrm{T} 4$ concentrations but reduced $\mathrm{T} 3$ concentrations in the brain. It is possible that there are other factors, apart from thyroid hormone levels per se in the fetal brain, that mediate the thyroid hormone-related pathogenesis of impaired neurodevelopment. Our understanding so far does not help us to ascertain whether the effects of maternal hypothyroidism on fetal brain development are completely mediated through a direct effect on the fetal thyroid status. In pregnancy these effects may be secondary to the impaired supply of iodide and T4 to the fetus, or through materno-fetal transfer of anti-thyroid antibodies. Alternatively, they may perhaps be mediated indirectly by maternal metabolic impairment and detrimental effects on placental function. It has been documented that $\mathrm{T} 3$ can stimulate the production of $17 \beta$-oestradiol and epidermal growth factor in human placenta, and may have a role in placental development (Maruo et al. 1991, Kilby et al. 1998).

\section{The placental transport of hormones and fetal pituitary function}

Circulating thyroid hormones in the human fetus are of both maternal and fetal origin, and their presence are dependent on a functioning placenta for $\mathrm{T} 4$ transport and supply of iodide substrate (Fig. 2). The placenta rapidly breaks down much of the T4 presented to it but significant amounts of T4 are still transferred (Delbert \& Fisher 1997b). The placenta is freely permeable to iodide and thyrotrophin-releasing hormone (TRH) but impermeable to TSH. Maternal TRH may have a role in controlling fetal thyroid function (Polk et al. 1991) before the maturation of the hypothalamic-pituitary-thyroid axis that occurs near term. TRH can be detected in the fetal hypothalamus by the end of the first trimester, at the same time as the thyroid begins to concentrate iodine. TSH can be found in the pituitary at 10-12 weeks gestation, with serum levels rising towards term to values exceeding those of the adult (Fisher et al. 1977, Thorpe-Beeston et al. 1991a). Our data has indicated that the human placenta expresses all thyroid hormone receptor (TR) isoforms (both protein and mRNA) and that this expression increases with gestational age (Kilby et al. 1998). The role of these receptors in placental tissue is unknown at present. 


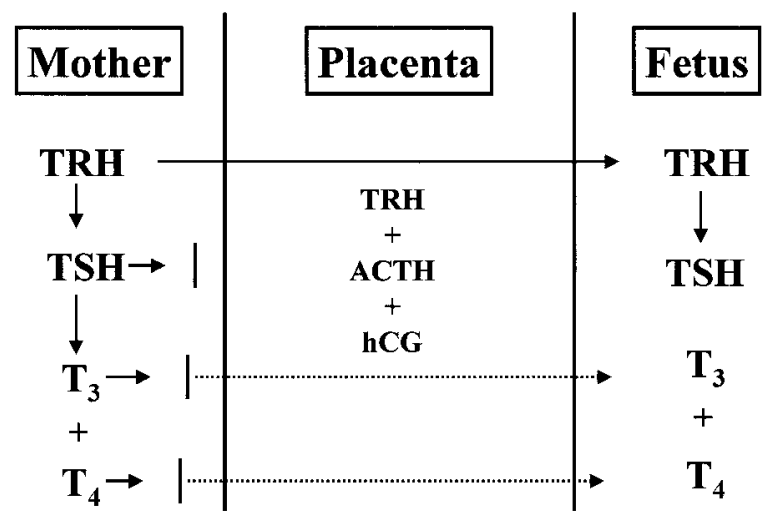

Figure 2 Classically the placenta has been considered as a 'barrier' to transfer of free T3 and T4 to the fetus. However, recent epidemiological data has rekindled interest as to the possibility of transplacental transfer of thyroid hormones to the fetus from early gestation. (TRH, thyroid releasing hormone; TSH, thyrotrophin; T3, triiodothyronine; T4, thyroxine; ACTH, adrenocorticotrophin; hCG, human chorionic gonadotrophin.)

\section{Thyroid hormone receptor expression and function in the human fetus}

The T3 binding capacity and TR concentration in the human fetal brain also rises steadily with gestation. A tenfold increase in the maximal binding capacity for $\mathrm{T} 3 \mathrm{in}$ human fetal brains between 10 and 16 weeks has been described (Bernal \& Pekonen 1984). However, the mere presence of TRs at any time does not necessarily imply a concurrent thyroid-dependent action as demonstrated by studies of the development of the cochlea in rats. Although TRs are present in the primitive cochlea from the twelfth day of gestation, the critical period for its thyroid hormone-dependent development is from the eighteenth day of gestation till the fifth postnatal day (Uziel 1986).

Four important TR isoforms have been characterised in humans. The erbA $\alpha$ locus on chromosome 17 encodes TR $\alpha 1$ and TR $\alpha 2$ proteins, whilst the erbA $\beta$ locus on chromosome 3 expresses TR $\beta 1$ and TR $\beta 2$ (Oppenheimer \& Schwartz 1997, Sinha et al. 1997). A greater than threefold rise in TR $\beta 1$ transcript levels between 11 and 22 weeks in human fetal brains has been described.

TR $\alpha 1, T R \beta 1$ and TR $\beta 2$ bind T3 with similar affinity and binding kinetics. The $\alpha 2$ protein does not bind T3 and a modulatory role mediated by competitive binding of protein to thyroid hormone response elements on DNA has been postulated (Koenig et al. 1989, Lazar et al. 1989). All TR isoform-mRNAs were detectable in fetal cerebral cortex using RT-PCR as early as 9 weeks. Weak immunostaining for $\operatorname{TR} \alpha 1$ and $\operatorname{TR} \alpha 2$ proteins within cortical pyramidal cells and cerebellar Purkinje cells in the first trimester has been described. By the second trimester all of the isoforms were expressed in the same areas. A rise of at least fourfold was observed for each isoform between the first and second trimester. By the third trimester every neuron in these same areas expressed all of the TR isoforms (Verhaeg et al. 1999).

The existence of various TR isoforms implies the presence of specific roles for each of them. For example, patients with homozygous deletion of the TR $\beta$ gene suffer with deaf-mutism but demonstrate normal cognitive function (Takeda et al. 1992). This implies a specific role for the $\operatorname{TR} \beta$ protein in the development of the auditory apparatus and cortex.

The TR proteins are characterised by a DNA binding domain containing two zinc fingers, a carboxy terminal that contains the ligand binding domain and the transactivation site, and finally an amino-terminal domain with a poorly defined function. The T3-TR complex binds to specific DNA sequences on thyroid hormone response elements (TRE) found in the regulatory regions of target genes (Oppenheimer et al. 1996, Onate et al. 1995). All the following research data concerning thyroid hormone-regulated gene expression have been gathered from animal models. Examples of such genes include myelin basic protein (MBP), myelin-associated glycoprotein (MAG) and proteolipid protein (PLP) whose mRNAs expressed in oligodendrocytes are reduced by at least $50 \%$ in hypothyroid fetal rats (Oppenheimer \& Schwartz 1997). The lack of these proteins may be implicated in the delayed myelination observed. Effective TREs have been found in the promoters of mouse MBP and PLP genes, suggesting direct regulation by the T3-TR complex (Bogazzi et al. 1994, Farsetti et al. 1991, 1992). The capacity of cultured cells to enhance MBP expression in response to T3 coincided with the appearance of TR $\beta 1 \mathrm{mRNA}$ (Strait et al. 1997). The cerebellar Purkinje cells express genes including calbindin, myo-inositol-triphosphate (IP3) receptor, and Purkinje cell protein-2 (PCP-2), all of which show significantly delayed mRNA expression in neonatal hypothyroid rats. Interestingly despite ultimate normalisation of these mRNA levels, the pups demonstrated a marked deficit in Purkinje cell maturation, confirming the importance of timing in thyroid hormone-dependent neurodevelopment (Strait et al. 1992). It has been postulated that there are suppressive factors that control the predetermined times at which thyroid hormone augmentation of specific genes should occur. It has been shown that injecting pregnant rats with large doses of T4 resulting in supraphysiological levels of T3 in fetal brains failed to augment the expression of PCP-2 and MBP prematurely (Schwartz et al. 1997). Potential suppressors, in the form of DNA binding nuclear proteins, have been found to bind to the promoter regions of the PCP-2 and MBP genes, and interestingly their disappearance coincides with the time the gene expression becomes thyroid hormone responsive (Anderson et al. 1997). 


\section{Extranuclear mechanisms of thyroid hormone action}

Only a limited number of specific genes in the CNS have been found to be directly regulated by thyroid hormones through ligand-receptor complexes binding to DNA response elements and the difficulty in identifying more has been surprising (Oppenheimer \& Schwartz 1997). In contrast to the examples above, the neurogranin (RC3) and calbindin mRNAs expressed in neurons are markedly depressed in hypothyroid rats but a functional TRE has not been identified upstream of these genes (Iniguez et al. 1993, 1994). This suggests the possibility of an indirect regulatory mechanism in action. It is possible that this mechanism could still involve the binding of T3-receptor complexes to DNA, for example through controlling the expression of genes encoding nucleoproteins that in turn regulate RC3 expression (Oppenheimer \& Schwartz 1997).

In vivo studies using animal models have raised the possibility of extranuclear thyroid hormone action but definitive evidence is lacking to date. The production of microtubule-associated proteins (MAP) and tau are altered by thyroid status but this difference is imperceptible at the mRNA level (Silva \& Rudas 1990, Nunez et al. 1991, 1992). It has been demonstrated that thyroid hormones can regulate the timing of the splicing mechanism involved in the replacement of juvenile tau mRNA with adult versions, so thyroid hormones may control post-transcriptional activity (Aniello et al. 1991).

Granular immunostaining of TRs has been reported within neuronal cell cytoplasm where they may have a role. In rats T3 binding sites have also been found on cell membranes, synaptosomes and in mitochondria (Sterling et al. 1977, Dratman et al. 1989). In the presence of thyroid hormones amino acid and glucose uptake by brain tissue is rapidly enhanced possibly through the direct regulation of membrane porosity (Buchanan \& Tapley 1966, Sinha et al. 1997, Pickard et al. 1987, 1991, 1997).

It is known that T4 can rapidly down-regulate the action of type II monodeiodinase, an activity which is affected by cytochalasin B but not cycloheximidine or actinomycin D. This suggests an action not mediated through gene expression and that requires an intact actin cytoskeleton (Leonard et al. 1990). It has been suggested that type II monodeiodinase binds actin $\mathrm{F}$ in the presence of T4 triggering the internalisation of the enzyme into endosomal pools by the movements of microfilamentous cytoskeletons (Farwell et al. 1993). This ability of thyroid hormones to influence cytoskeletal activity in this way raises the possibility that similar mechanisms involving different cytoplasmic proteins could be responsible for neuronal migration, dendritic and axonal elongation and neuronal differentiation (Lauffenburger \& Horwitz 1996, Mitchison \& Cramer 1996).
Intrauterine growth restriction and prematurity in human pregnancy

Fetal development and growth depend on several endocrine, paracrine and autocrine events within the fetoplacental unit (Hill 1988). Malfunction of this unit can result in intrauterine growth restricted (IUGR) fetuses, with brain weight usually maintained relative to body weight while other organs like the liver are significantly smaller. IUGR babies contribute significantly to perinatal and neonatal mortality and morbidity. Ten per cent of low birth weight babies suffer some degree of physical handicap (Gaffney 1994) and 5\% show neurodevelopmental delay at age 9 (Kok et al. 1998). In utero fetal blood sampling has shown that fetuses with severe IUGR have significantly lower levels of circulating free $\mathrm{T} 4$, free $\mathrm{T} 3$ and a slight elevation in TSH (Thorpe-Beeston et al. 1991b, Kilby et al. 1998). Very low birth weight (VLBW) infants also have lower serum total T4 and T3 concentrations (Klein et al. 1997). This is accompanied by a reduction in the expression of all TR isoforms in the cerebellum and cerebral cortices of the IUGR fetus (Verhaeg et al. 1999). Histological abnormalities, which are similar to those described in thyroid deficiency, have also been noted in the cerebral and cerebellar cortices of growth restricted animal models (Mallard et al. 1998). Therefore thyroid status has been postulated to play a role in the pathogenesis of neurodevelopmental impairment in IUGR and VLBW infants.

Premature infants of less than 30 weeks gestational age (not necessarily with IUGR) also experience a transient period of hypothyroxinaemia with a fall in serum free T4 concentrations without TSH elevation. These neonates have a problem with autoregulation of thyroidal iodine uptake as well as an immature hypothalamic-pituitarythyroid axis resulting in an inability to compensate for the loss of maternal T4 supply in the short term (Rooman et al. 1996, Ares et al. 1997, Delbert \& Fisher 1997a, Van Wassenaer et al. 1997). Comparing free T4 concentrations of premature infants with intrauterine fetuses of similar gestational age revealed a 50\% difference initially, a phenomenon not observed in term babies (Ares et al. 1997). This difference is regarded by many neonatologists to represent a physiological response because thyroid hormone supplementation in premature infants has not demonstrated any clear benefit to the long-term neurodevelopment of these infants (Chowdry et al. 1984). However analysis of a subgroup of neonates of 25-26 weeks gestational age showed a higher IQ in the treated group compared with placebo treated controls. Conversely, oversupplementation in neonates older than 27 weeks gestational age has been associated with a reduction in mean IQ relative to controls (Van Wassenaer et al. 1997). However there are only a few studies of thyroid supplementation in premature infants, with small numbers of patients, and these initial results need further verification. 


\section{Conclusions}

There is strong evidence pointing towards a crucial role for thyroid hormones in fetal brain development. This is supported by evidence at histological, biochemical and molecular levels mainly in animal models. There needs to be caution when extrapolating these findings to humans. Initial research on human fetuses has shown many parallel findings especially regarding the thyroid hormone levels and receptors in fetal brains. The precise timing for thyroid hormone-dependent central nervous system development in the human fetus is, however, unclear, and may be phasic and different for specific areas of the brain. The relative contribution of maternal and fetal thyroid hormones to brain development is also unclear. We know that some degree of compensation occurs if one or other is lacking, but differences in the neuropsychological development are still demonstrable in either case compared with euthyroid controls. There is suggestion that reduction in circulating thyroid hormone concentrations is one of the factors mediating impaired neurological development in IUGR, VLBW and premature babies. More research is required to resolve these questions and ultimately show if thyroid hormone or iodide supplementation in hypothyroid mothers in the antenatal period and in premature neonates can reduce the prevalence of neurodevelopmental delay.

\section{References}

Anderson GW, Larson RJ, Schwartz HL, Mariash CN \& Oppenheimer JH 1997 COUP-TF may regulate Purkinje cell protein-2 responsivity to thyroid hormone during development. Program of the $79^{\text {th }}$ Annual meeting of the Endocrine Society, Abstract OR15-5.

Aniello F, Couchie D, Bridoux AM, Gripois D \& Nunez J 1991 Splicing of juvenile and adult tau mRNA variants is regulated by thyroid hormone. Proceedings of the National Academy of Sciences of the USA 88 4035-4039.

Ares S, Escobar-Morreale HF \& Quero J 1997 Neonatal hypothyroxinaemia; effects of iodine intake and premature birth. Journal of Clinical Endocrinology and Metabolism 82 1704-1712.

Balazs R, Brooksbank BW, Davison AN, Eayrs JT \& Wilson DA 1969 The effect of neonatal thyroidectomy on myelination in the rat brain. Brain Research 15 219-232.

Balazs R, Kovacs S, Cocks WA, Johnson AL \& Eayrs JT 1971 Effect of thyroid hormone on the biochemical maturation of rat brain: postnatal cell formation. Brain Research 25 555-570.

Bernal J \& Pekonen F 1984 Ontogenesis of the nuclear $3,5,3^{\prime}$ triiodothyronine receptor in human fetal brain. Endocrinology 114677.

Bogazzi F, Hudson LD \& Nikodem VM 1994 A novel heterodimerization partner for thyroid hormone receptor. Journal of Biological Chemistry 269 11683-11686.

Buchanan J \& Tapley DF 1966 Stimulation by thyroxine of amino acid incorporation into mitochondria. Endocrinology 79 81-89.

Burrow GN, Fisher DA \& Larsen PR 1994 Maternal and fetal thyroid function. New England Journal of Medicine 331 1072-1078.

Calvo R, Obregon MJ, Ruiz de Ona C, Escobar del Rey F \& Morreale de Escobar G 1990 Congenital hypothyroidism as studied in rats: crucial role of maternal thyroxine but not of 3,5,3 triiodothyronine in the protection of the fetal brain. Journal of Clinical Investigation 86 889-899.

Cao XY, Jiang XM, Dou ZH, Rakeman MA, Zhang ML, O’Donnell K, Ma T, Amette K, DeLong N \& DeLong GR 1994 Timing of vunerability of the brain to iodine deficiency in endemic cretinism. New England Journal of Medicine 331 1739-1744.

Chowdry P, Scanlon JW, Auerbeck R \& Abbassi V 1984 Results of controlled double-blind study of thyroid replacement in very low birth weight premature infants with hypothyroxinaemia. Pediatrics 73 301-305.

de Zegher F, Permasetti F, Vanhole C, Devlieger H, Van den Berghe G \& Martial JA 1995 The prenatal role of thyroid hormone evidenced by fetomaternal Pit-1 deficiency. Journal of Clinical Endocrinology and Metabolism 80 3127-3130.

Delbert A \& Fisher MD 1997a Editorial: The hypothyroxinemia of prematurity. Journal of Clinical Endocrinology and Metabolism $\mathbf{8 2}$ 1701-1703.

Delbert A \& Fisher M 1997b Fetal thyroid function: diagnosis and management of fetal thyroid disorders. Clinical Obstetrics and Gynaecology 40 16-31.

Dratman MB, Crutchfield FL \& Gordon JT 1989 In Iodine and the Brain, p 151. Eds GR Delong, J Robbins \& PR Condliffe. New York: Plenum Press.

Dussault JH \& Fisher DA 1999 Thyroid function in mother of hypothyroid newborns. Obstetrics and Gynaecology 93 15-20.

Eayrs JT 1955 The cerebral cortex of normal and hypothyroid rats. Acto Anatomy 25 160-183.

Eayrs JT 1971 Thyroid and developing brain: anatomical and behavioural effects. In Hormones in Development, pp 345-355. Eds M Hamburgh \& E Barrington. New York: Appleton-Century-Crofts.

Eayrs JT \& Horne G 1955 The development of cerebral cortex in hypothyroid and starved rats. Anatomical Record 121 53-61.

Eayrs JT \& Taylor SH 1951 The effect of thyroid deficiency induced by methylthiouracil on the maturation of the central nervous system. Journal of Anatomy 85 350-358.

Faivre C, Legrand C \& Rabie A 1984 In Purkinje cell dendrites of the young rat, thyroid hormone controls the resistance of microtubules to fixation at low temperature. International Journal of Developments in Neuroscience 2 427-436.

Farsetti A, Robbins J \& Nikodem V 1991 Molecular basis of thyroid hormone regulation of myelin basic protein gene expression in rodent brain. Journal of Biological Chemistry 266 23226-23232.

Farsetti A, Desvergne B, Hallenbeck P, Robbins J \& Nokodem VM 1992 Characterisation of myelin basic protein thyroid hormone response element and its function in the context of native and heterologous promoter. Journal of Biological Chemistry 267 15784-15788.

Farwell A, DiBenedetto D \& Leonard J 1993 Thyroxine targets different pathways of internalisation of type II iodothyronine $5^{\prime}$-deiodinase in astrocytes. Journal of Biological Chemistry 268 $5055-5062$.

Fisher DA 1991 Screening for congenital hypothyroidism. Trends in Endocrinology and Metabolism 2 129-133.

Fisher DA 1992 Endocrinology of fetal development. In Textbook of Endocrinolog $\gamma$, edn 8, pp 1049-1077. Eds JD Wilson \& DW Foster. Philadelphia: WB Saunders.

Fisher DA, Dussault JH, Sacks J \& Chopra IJ 1977 Ontogenesis of hypothalamic pituitary thyroid function and metabolism in man, sheep and rat. Recent Progress in Hormone Research 33 59-116.

Fisher DA, Dussault JH, Foley TP Jr, Klein AH, LaFranchi S, Larsen PR, Mitchell ML, Murphy WH \& Walfish PG 1979 Screening for congenital hypothyroidism: results of screening one million North American infants. Journal of Pediatrics 94 700-705.

Gaffney G 1994 A case-controlled study of intrapartum care, cerebral palsy and perinatal death. British Medical Journal 308 743-750.

Haddow JE, Glenn E, Palomaki BS, Walter C, Allan MD, Williams JR, Knight GJ, Gagnon J, O’Heir CE, Mitchell ML, Hermos RJ, 
Waisbren SE, Faix JD \& Klein RZ 1999 Maternal thyroid deficiency during pregnancy and subsequent neuropsychological development of the child. New England Journal of Medicine 341 549-555.

Heyerdahl S 1991 Intellectual development in children with congenital hypothyroidism in relation to T4 replacement. Journal of Pediatrics 118 850-855.

Hill D 1988 Hormonal control of fetal growth. In Fetus and neonate, vol 3. Eds CH Rodeck, M Hanson \& J Spencer. New York: Cambridge University Press.

Illig R 1979 Congenital hypothyroidism. Clinical Endocrinology and Metabolism 8 49-62.

Iniguez MA, Rodriguez-Pena A, Ibarrola N, Aguilera M, Munoz A \& Bernal J 1993 Thyroid hormone regulation of RC3, a brain specific gene encoding a protein kinase-C substrate. Endocrinology 133 467-473.

Iniguez MA, Morte B, Rodroguez-Pene A, Munoz A, Gerendasy D, Sutcliffe JG \& Bernal J 1994 Characterisation of the promoter region and flanking sequences of the neuron-specific gene RC3(neurogranin). Brain Research Molecular Brain Research 27 205-214.

Karmarkar MG, Prabarkaran D \& Godbole M 1993 5'-Monodeiodinase activity in developing human cerebral cortex. American Journal of Clinical Nutrition 57 291S-294S.

Kilby MD, Verhaeg J, Gittoes N, Somerset DA, Clarke P \& Franklyn JA 1998 Circulating thyroid hormone concentrations and placental thyroid hormone receptor expression in normal human pregnancy and pregnancy complicated by intrauterine growth restriction. Journal of Clinical Endocrinology and Metabolism 83 2964-2971.

Klein RZ, Carlton EL \& Faix JD 1997 Thyroid function in very low birthweight infants. Clinical Endocrinology 47 419-421.

Koenig RJ, Lazar MA, Hodin RA, Brent GA, Larsen PR, Chin WW \& Moore DD 1989 Inhibition of thyroid hormone action by a non-hormone binding c-erbA protein generated by alternate mRNA splicing. Nature 337 659-661.

Kok JH, den Ouden LA, Verloove-Vanhorick SP \& Brand R 1998 Outcome of very preterm small for gestational age infants: the first nine years. British Journal of Obstetrics and Gynaecology 105 162-168.

Lauffenburger DA \& Horwitz AF 1996 Cell migration: a physically integrated molecular process. Cell 84 359-369.

Lazar MA, Hodin RA \& Chin WW 1989 Human carboxy-terminal variant of $\alpha$-type c-erbA inhibits transactivation by thyroid hormone receptors without binding thyroid hormone. Proceedings of the National Academy of Sciences of the USA 86 7771-7774.

Legrand J 1967 Variations, en fonction de l'age, de la reponse du cervelet a l'action morphogenetique de la thyroide chez le rat. Archives of Anatomy and Microscopic Morphology Experiments $\mathbf{5 6}$ 291-307.

Legrand J 1986 Thyroid hormone effects on growth and development. In Thyroid Hormone Metabolism, pp 503-534. Ed. G Henneman. NewYork: M. Dekker, Inc.

Leonard JL, Silva JE, Kaplan MM, Mellen SA, Visser TJ \& Larsen PR 1984 Acute post-transcriptional regulation of cerebrocortical and pituitary iodothyronine $5^{\prime}$-deiodinases by thyroid hormone. Endocrinology 114 998-1004.

Leonard JL, Siegrist-Kaiser CA \& Zuckerman CJ 1990 Regulation of type II iodothyronine $5^{\prime}$-deiodinase by thyroid hormone: inhibition of actin polymerization blocks enzyme activation in cAMPstimulated glial cells. Journal of Biological Chemistry 265 940-946.

Mallard EC, Rees S, Stringer M, Cock M \& Harding R 1998 Effects of chronic placental insufficiency on brain development in fetal sheep. Pediatric Research 43 262-270.

Man EB, Brown JF \& Scrunian SA 1991 Maternal hypothyroxinemia: psychoneurological deficits of progeny. Annals of Clinical and Laboratory Science 21 227-239.

Maruo T, Matsuo H \& Mochizuki M 1991 Thyroid hormone as a biological amplifier of differentiated function in early pregnancy. Acta Endocrinologica 125 58-66.
Mitchison TJ \& Cramer LP 1996 Actin-based cell motility and cell locomotion. Cell 84 371-379.

New England Congenital Collaborative 1990 Elementary school performance of children with congenital hypothyroidism. Journal of Pediatrics 116 27-32.

Nicholson JL \& Altman J 1972 The effects of early hypo- and hyperthyroidism on the development of the rat cerebellar cortex. I.Cell proliferation and differentiation. Brain Research 44 13-23.

Nunez J, Couchie D, Aniello F \& Bridoux A 1991 Regulation by thyroid hormone of microtubule assembly and neuronal differentiation. Neurochemistry Research 16 975-982.

Nunez J, Couchie D, Aniello F \& Bridoux A 1992 Thyroid hormone effects on neuronal differentiation during brain development. Acta Medica Austriaca 19 36-39.

Onate SA, Tsai SY, Tsai MJ \& O’Malley BW 1995 Sequence and characterisation of a co-activator for the steroid hormone receptor superfamily. Science 270 1354-1357.

Oppenheimer JH \& Schwartz HL 1997 Molecular basis of thyroid hormone-dependent brain development. Endocrine review 18 462-475.

Oppenheimer JH, Schwartz HL \& Strait KA 1996 The molecular basis of thyroid hormone actions. In The Thyroid, edn 7, pp 162-184. Eds L Braverman \& R Utiger. Philadelphia: Lippincott-Raven.

Pharoah P, Buttfield IH \& Hetzel BS 1971 Neurological damage to the fetus resulting from severe iodine deficiency during pregnancy. Lancet i 308-310.

Pharoah P, Connolly K, Elkins R \& Harding A 1984 Maternal thyroid hormone levels in pregnancy and the subsequent cognitive and motor performance of the children. Clinical Endocrinology 21 265-270.

Pickard M, Evans I, Bandopadhyay R, Leonard A, Sinha A \& Ekins R 1997 Thyroid hormone action in rat brain from fetal to adult life. Recent Research Developments in Neuroendocrinology - Thyroid hormone and brain maturation, pp 15-29.

Pickard MR, Sinha AK, Gullo D, Patel N, Hubank MJ \& Ekins RP 1987 The effect of 3,5,3'triiodothyronine on leucine uptake and incorporation into protein in cultured neurons and subcellular fractions of rat central nervous system. Endocrinology 121 2018-2026.

Pickard MR, Sinha AK, West S \& Holland T 1991 In Progress in thyroid research, p 919. Eds A Gordon, J Gross \& G Hennemann. Rotterdam: Balkema Publishers.

Polk DH, Reviczky A, Lam RW \& Fisher DA 1991 Thyrorophin releasing hormone in the ovine fetus: ontogeny and effect of thyroid hormone. American Journal of Physiology 260 E53-E58.

Pop VJ, Kuijpens JL, van Baar AL, Verkerk G, van Son MM, de Vijlder JJ, Vulsma T, Wiersinga WM, Drexhage HA \& Vader HL 1999 Low maternal free thyroxine concentrations during early pregnancy are associated with impaired psychomotor development in infancy. Clinical Endocrinology 50 149-155.

Rooman RP, DuCaju MVL, Op De Beeck L, Docx M, Van Reempts P \& Van Acker RT 1996 Low thyroxinaemia occurs in the majority of very preterm newborns. European Journal of Pediatrics 155 211-215.

Rosman NP, Malone MJ, Helfenstein M \& Kraft E 1972 The effect of thyroid deficiency on myelination of brain. Neurology 22 99-106.

Rovet JF, Ehrlich RM \& Sorbara DL 1992 Neurodevelopment in infants and preschool children with congenital hypothyroidism: etiological and treatment factors affecting outcome. Journal of Pediatric Psychology 17 187-213.

Schwartz HL, Ross ME \& Oppenheimer JH 1997 Lack of effect of thyroid hormone on late fetal rat brain development. Endocrinology 138 3119-3124.

Silva JE \& Rudas P 1990 Effects of congenital hypothyroidism on microtubule-associated protein-2 expression in the cerebellum of the rat. Endocrinology 126 1276-1282. 
Sinha AK, Pickard MR, Kim KD, Ahmed MT, al Yatama F, Evans IM \& Ekins RP 1994 Perturbation of thyroid hormone homeostasis in the adult and brain function. Acta Medica Austriaca 21 35-43.

Sinha A, Prabakaran D, Godbole M, Chattopadhyay N, Karmarkar M, Pickard M, Leonard A \& Ekins R 1997 Recent Research Developments in Neuroendocrinology - Thyroid hormone and Brain Maturation, pp 1-14.

Sterling K, Milch PO, Brenner MA \& Lazarus JH 1977 Thyroid hormone action: the mitochondrial pathway. Science 197177.

Strait K, Carlson D, Schwartz H \& Oppenheimer JH 1997 Transient stimulation of MBP gene expression in differentiating cultured oligodendrocytes: a model for T3-induced brain development. Endocrinology 138 635-641.

Strait KA, Zou L \& Oppenheimer JH $1992 \beta 1$ isoform-specific regulation of a triiodothyronine-induced gene during cerebellar development. Molecular Endocrinology 6 1874-1880.

Takeda K, Sakurai A, DeGroot L \& Refetoff S 1992 Recessive inheritance of thyroid hormone resistance caused by complete deletion of the protein-encoding region of the thyroid hormone receptor- $\beta$ gene. Journal of Clinical Endocrinology and Metabolism $\mathbf{7 4}$ $49-55$.

Thorpe-Beeston JG, Nicolaides KH, Felton CV, Butler J \& McGregor AM 1991a Maturation of the secretion of thyroid hormone and thyroid-stimulating hormone in the fetus. New England Journal of Medicine 324 532-536.
Thorpe-Beeston JG, Nicolaides KH, Snidjers RJ, Felton CV \& McGregor AM $1991 b$ Thyroid function in small for gestational age fetuses. Obstetrics and Gynecology 77 701-706.

Thorpe-Beeston JG, Nicolaides KH \& McGregor AM 1992 Fetal thyroid function. Thyroid 2 207-217.

Uziel A 1986 Periods of sensitivity to thyroid hormone during development of the organ of Corti. Acta Oto-laryngolica supplement $42923-27$.

Van Wassenaer AG, Kok JH, DeVijlder JJ, Briet JM, Smit BJ, Tamminga P, Van Baar A, Dekker FW \& Vulsma T 1997 Effects of thyroxine supplementation on neurologic development in infants born at less than 30 weeks gestation. New England Journal of Medicine $33621-26$.

Verhaeg J, Gittoes N, Janniaux E, Franklyn KA \& Kilby MD 1999 Determination of early expression of thyroid receptor isoforms in the human fetal nervous system. Journal of Endocrinology OC23.

Vulsma T, Gons M \& de Vijlder JM 1989 Maternal-fetal transfer of thyroxine in congenital hypothyroidism due to a total organification defect or thyroid dysgenesis. New England Journal of Medicine 321 $12-16$.

Received 23 September 1999

Accepted 2 December 1999 